\title{
Youth, Life, and Politics: Examining the Everyday in Comparative Politics
}

Maria Ortuoste, California State University, East Bay

ABSTRACT The traditional way of introducing comparative politics to freshmen, which is through the study of institutions, is contrasted with an alternative approach. An everydaypolitics approach compares the daily struggles of global youth-how they cope in times of peace and war, and with issues of wealth and poverty, identity, education and employment, and citizenship and immigration. This approach contains four elements: juxtapositions, recognition of the vicissitudes of growing up in a more complex world, the use of stories, and social action in our daily lives. This combination "gently" introduces the concepts of comparative politics but with an emphasis on how politics affect the lives of other young people. These stories also show the various forms of political participation and political resistance in different countries. An everyday-politics approach, while still experimental, seems to yield some positive results in helping students care about politics, gaining an understanding of how much is at stake for them, and connecting them to the wider world.

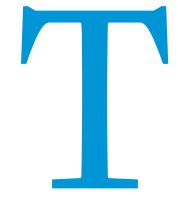

eaching an introductory course in comparative politics (CP) to freshmen nonmajors is challenging. How do we communicate the richness of the discipline to a cohort of students who, according to several surveys, are more concerned with daily life management rather than global affairs? More importantly, how can we evoke a sense of civic responsibility beyond our classrooms? ${ }^{1}$

One solution is to refocus content and pedagogy. We can move from a narrow conception of politics in the formal arena to an examination of myriad forms of political engagements; from a focus on relatively static institutions to a focus on global youth and the changes they bring; and from a lecture class to an activelearning community. In short, we can strive to engage in a critical examination of global youth as they experience the politics of the everyday.

This article first discusses an introductory course that was based on a traditional structure. Second, a content analysis of CP textbooks shows that they do not reflect current youth concerns as well as latest scholarly research about the alternative political engagements of young people. Third, a new course structure that focuses on the everyday as the intersection of macro and micropolitics and the site of youth agency is reviewed. The course content is combined with a pedagogical

Maria Ortuoste is an assistant professor in the department of political science at California State University, East Bay. Her research revolves around the international relations of the Asia-Pacific and the evolution of regional institutions. She is currently looking at the role of discourse in human rights, regional identity, and environmental governance. She can be reached at maria.ortuoste@csueastbay.edu. technique that uses textbooks and stories to encourage "doing, observing, and reflecting." Finally, the article discusses the application of this everyday approach in another introductory course on $\mathrm{CP}$.

\section{FIRST FORAY WITH FRESHMEN}

I adopted a traditional approach for my first introductory CP course. It provided an overview of the big, important theories and concepts followed by a discussion of country cases. To encourage interaction, small-group discussions were organized on identity and ideology, democracy, and current issues. The final activity was a simulation where European-type parties (e.g., National Front, Socialists, Green Party) presented their platforms and tried to form a parliament (Anderson 2007). Later in the term, students provided weekly news reports on "adopted" countries.

The results were fairly typical of political science classes: those who were already interested in the field did well, and those who just wanted to get through the class as quickly and as painlessly as possible did not. The students were not as engaged as I had hoped, and I doubt if the students developed any appreciation for the importance of politics.

There were two possible reasons for this "failure." First, this traditional approach did not make politics tangible for students. The realm of formal politics in the United States, let alone the rest of the world, was too alien and appeared to be the business of "old" people. This led to a second possible reason: this topdown approach highlighted the inconsequence of young people. If they could not imagine how they fit in the political world, 


\begin{tabular}{|c|c|}
\hline & $\begin{array}{l}\text { NUMBER OF } \\
\text { TEXTBOOKS }\end{array}$ \\
\hline \multicolumn{2}{|l|}{ Concepts/Theories } \\
\hline Democracy; authoritarianism; identity; state & 6 \\
\hline $\begin{array}{l}\text { Transitions; political institutions; economic } \\
\text { systems }\end{array}$ & 5 \\
\hline $\begin{array}{l}\text { Presidential versus parliamentary system; } \\
\text { political parties; political culture; civil society } \\
\text { and civic culture }\end{array}$ & 4 \\
\hline Revolution; political economy; colonialism & 3 \\
\hline $\begin{array}{l}\text { Legitimacy; military; development; political } \\
\text { violence }\end{array}$ & 2 \\
\hline Power & 1 \\
\hline \multicolumn{2}{|l|}{ Issues } \\
\hline Economy & 5 \\
\hline $\begin{array}{l}\text { Conflict; gender and women; environment; } \\
\text { human rights }\end{array}$ & 4 \\
\hline Religion & 3 \\
\hline Social welfare; corruption & 2 \\
\hline \multicolumn{2}{|l|}{ Countries } \\
\hline US; Germany; China; Nigeria & 6 \\
\hline UK; Russia; France; India; Iran; Japan & 5 \\
\hline Mexico; Brazil & 4 \\
\hline South Africa; Sweden & 3 \\
\hline $\begin{array}{l}\text { Iraq; Turkey; Egypt; Israel; Palestine; former Yugoslavia } \\
\text { (the last } 3 \text { were short write-ups) }\end{array}$ & 2 \\
\hline
\end{tabular}

especially if their careers lie elsewhere, what was the point of studying politics?

The country adoptions and weekly news reports were more successful. Some students commented that the exercise helped them to look more deeply into countries and to realize that other people faced similar problems such as the education and economic crises. From this experience, I "hypothesized" that it was possible to make students more responsible for learning about, and appreciating, politics if the course highlighted their own concerns. But this was easier said than done.

\section{RE-EXAMINING CONTENT AND AUDIENCE}

Retooling the course required a close examination of selected textbooks as well as knowing more about the audience. This review showed that there was a disconnect between (a) our textbooks and current global realities including the plight of youth and (b) our course content and latest research regarding youth concerns and their alternative political actions. To be precise, young people are invisible in these textbooks. If they are discussed, it is only as hapless victims of unfortunate political decisions.

Seven textbooks were analyzed for their organizational structure, and the countries and issues discussed (see table 1 )..$^{2}$ In terms of organizational structure, four textbooks followed the conventional approach of discussing concepts, theories, some current issues, and country case studies (Hauss 2009; O'Neil 2007; O'Neil, Fields, and Share 2007; and Sodaro 2008). Other texts presented a statistical analysis of all countries in terms of regime structure
(Siaroff 2009), a disaggregation of selected countries (Drogus and Orvis 2009), and short country examples (Danziger 2009; Sodaro 2008).

The textbooks provided excellent discussions of core conceptsregimes, institutions, transitions, economic systems-and included more recent issues such as ethnicity, religion, nationalism, globalization, economy, conflict, and gender. As scholars, we know these issues have an impact on young people, yet such a connection is not easily evident to young readers. Except for Hauss' (2009) discussion of child soldiers, there was no mention of youth or the issues identified by the United Nations as key concerns of youth. These concerns include: education, employment, hunger, health, drug abuse, juvenile delinquency, managing leisure time, intergenerational relations, and the "full and effective participation of youth in the life of society and in decision-making" (United Nations 1996).

Moreover, although the more recent textbooks endeavored to include a wider range of countries as identified in table 1 , a close reading showed that just a few countries were discussed in depth, and the rest were either short illustrations of concepts or captured only a snippet of life. This invisibility is all the more surprising considering that young people from ages 15 to 24 comprise around $18 \%$ of the world's population. Eight-five percent of global youth live in developing countries with 60\% in Asia and 23\% in Africa, Latin America, and the Caribbean (United Nations 2006). In the US alone, $34 \%$ of the population is less than 24 years old, with 18-24 year olds comprising $10 \%$ of the entire population. This group has also become more racially and ethnically diverse over the past 35 years (Lopez and Marcelo 2006).

Yet, one could ask if including youth concerns would even matter. Recent studies show that young Americans (ages 18-24) have low political and international knowledge, and they choose life goals that are not connected to civic-mindedness (Bennett and Bennett 2001; CHED 2010; Digeorgio Lutz 2010; Liu, Sharkness, and Pryor 2008; Lopez et al. 2006; Russell 2004; Wattenberg 2007). Sociological studies found that young people were more concerned with daily life management-that is, relationships, balancing leisure and work-and were also loath to challenge their self-understandings (Clydesdale 2007; Lang 2008). An anonymous survey I administered to 60 freshmen in spring 2009 yielded similar results. Most students rated themselves as having medium to a low level of awareness of political issues. When asked about what comes to mind when they hear the term "politics," they answered voting, institutions, power, and policy makers. Some students mentioned greed, lies, boring, chaotic, or no interest. Asked about their university life, they noted their challenges as managing time, balancing academics and socials, and coping with stress.

Yet, this is only one side of youth. The 2008 presidential campaign, for example, showed a record turnout for first-time voters. The 2010 National Election Pool National Exit poll also showed that $85 \%$ of young adults who voted in the 2010 midterm elections also voted during the 2008 presidential elections (CIRCLE 2010). Such youth engagement was also evident in other democracies such as in India and Japan. although authoritarian settings have not stopped the political activism of students.

Current research in various disciplines has examined the various ways that children and young people are social agents. These bodies of work include new geographies and social studies of childhood (Holt and Holloway 2006), the Chicago and Birmingham schools of sociology, and the anthropology of youth (Bucholz 
Table 2

\section{Summary of New Introductory Comparative Politics Course}

\section{COUNTRY/IES AND MATERIALS}

THEMES/CONCEPTS

\begin{tabular}{|c|c|}
\hline \multicolumn{2}{|l|}{ US: } \\
\hline $\begin{array}{l}\text { - '“Each and Every Single Story about Me ... There's Like a Huge } \\
\text { Twist to It": Growing Up at Risk in the US -A portrait of Mike' } \\
\text {. “'All My Life, I've Bounced Around': A Portrait of Blacc" }\end{array}$ & $\begin{array}{l}\text { "Advanced" democracy; youth homelessness and alternative families; } \\
\text { consequences of No Child Left Behind; drug problem; education }\end{array}$ \\
\hline \multicolumn{2}{|l|}{ UK: } \\
\hline $\begin{array}{l}\text { - "Young, White, Male, and Working Class: A Portrait of Richard" } \\
\text { - "Young, Deaf, and Lesbian: A Portrait of Susannah" } \\
\text { - Film, "My Beautiful Launderette" }\end{array}$ & $\begin{array}{l}\text { "Advanced" democracy; race and immigration; economic and social } \\
\text { classes; sexuality; neoliberal economics; coping with physical challenges }\end{array}$ \\
\hline Is Voting for Young People? & Voting and civic engagement \\
\hline \multicolumn{2}{|l|}{ India: Asia's largest democracy } \\
\hline $\begin{array}{l}\text { - Film, "Slumdog Millionaire" } \\
\text { - "Saka: Growing Up in the Indian Himalayas" } \\
\text { - "From Footballs to Fixer: Suresh and the New Politicians in North India" } \\
\text { - News clip: recent elections in India and use of YouTube }\end{array}$ & $\begin{array}{l}\text { Democracy; poverty and untouchables; urban-rural divide; education; } \\
\text { youth politics in India; getting out the youth vote; traditional roles of boys } \\
\text { and girls; dreams and realities }\end{array}$ \\
\hline \multicolumn{2}{|l|}{ Japan } \\
\hline $\begin{array}{l}\text { - Dana Goodyear, "I Novels" } \\
\text { - Documentary, "Japanese Education in Crisis" }\end{array}$ & $\begin{array}{l}\text { Discipline; competition and economic crisis; student stress and youth } \\
\text { violence; youth innovation and self-expression }\end{array}$ \\
\hline \multicolumn{2}{|l|}{ China } \\
\hline $\begin{array}{l}\text { - Documentary on Tiananmen Square } \\
\text { - Documentary, "From Maoism to Me-ism" }\end{array}$ & $\begin{array}{l}\text { Authoritarian government and communism; social and economic } \\
\text { transformations in the face of globalization; traditional and modern } \\
\text { values }\end{array}$ \\
\hline \multicolumn{2}{|l|}{ Conflicts and Terrorism: Sierra Leone and South Africa } \\
\hline $\begin{array}{l}\text { - Ishmael Beah, A Long Way Gone } \\
\text { - “Vusi Majola: 'Walking until the Shoes is Finished'” } \\
\text { - "Young, Male, Scottish and Muslim: A Portrait of Kabir" } \\
\text { - "Rocks: A Portrait of Mohammed" }\end{array}$ & $\begin{array}{l}\text { Civil war, child soldiers; apartheid; terrorism; Muslims; multiple identities } \\
\text { and fear; adjusting to post-conflict situations; violence and modes of } \\
\text { resistance (including music) }\end{array}$ \\
\hline \multicolumn{2}{|l|}{ Alternative Political Involvements, Globalization and Local Lives } \\
\hline $\begin{array}{l}\text { - Tanzania: "Telling Nala's Story: Negotiating the Global Agendas } \\
\text { and Local Politics of Maasai Development in Tanzania" } \\
\text { - US: Is Voting for Young People, chapter } 8 \\
\text { - UK/US: "Darkest Whiteness: Race, Class and Culture in Global Times: } \\
\text { A Portrait of Helena" } \\
\text { - "Afterword: Global Portraits and Local Snapshots" }\end{array}$ & $\begin{array}{l}\text { Spectrum of political actions; working with NGOs; blurring physical } \\
\text { boundaries, but continuing social divisions; social change at the local } \\
\text { level }\end{array}$ \\
\hline
\end{tabular}

2002). Specific studies look not only at the supposed political apathy and parochialism of young people (Fisher 2008; Harris and Wyn 2009; Pacheco 2008; Russell 2004; Wattenberg 2007) but also review alternative political engagements in different geographical, political, and cultural settings. These topics include digital media participation (Baumgartner and Morris 2010; Burwell 2010); citizenship practices (Keating, Benton, and Kerr 2011); new social spaces brought about by globalization (Kennelly, Poyntz, and Ugor 2009); political mobilization in different countries such as the Ukraine, Uzbekistan, and Germany (McGlinchey 2009; Gaiser et al. 2007; Topalova 2006); youth discourse in Hong Kong (Tam 2011); the coping strategies of unemployed young men in the global south (Jeffrey 2008); electronic dance music culture in the UK (Riley, Griffin, and Morey 2010); youthproduced election songs in postconflict Sierra Leone (Shepler 2010); patrimonial politics and the role of youth in communal politics in Nigeria (von Hellermann 2010); and the emergence roles of young global justice activists (Juris and Pleyers 2009).

\section{GLOBAL YOUTH AND EVERYDAY POLITICS: CONTENT}

The abovementioned studies show that the realm young people inhabit is the "everyday" (Scott 1985), that is, the intersection of macro and micropolitics. Young people have to deal with the consequences of politics, that is structures or conventional politics, while having to deal with micropolitics, specifically, their evolving identities and how they negotiate their place in the world (Philo and Smith 2003). It is this site where scholars have demonstrated young people developing alternative cultures, practices, and forms of resistance. These kinds of discussions could be productive in the classroom. In a study of young Australians, Harris and Wyn found that "Where personal experience, social interaction and everyday practice became part of politics, these young people felt better able to articulate political views and take social action" (2009, 342).

In this vein, the everyday-politics approach I designed consists of three elements: (1) juxtapositions; (2) a discussion of how youth processes unfold in different milieus; and (3) social action and agency in our daily lives. (See table 2 for a summary of the content for the new course.)

First, everyday political issues are presented in juxtaposition with key concepts in comparative politics-poverty and homelessness in "advanced democracies," the persistence of racial and gender discrimination in free societies, alternative forms of selfexpression in a highly disciplined society, pockets of normalcy 
during war and postconflict reconstruction, and the connections between the global and the local. These displacements, or misplacements, reveal what lies beneath the formal structures of government and make explicit connections between macro and micropolitics thus opening various areas for critical discussion.

Second, this approach acknowledges the difficulty of growing up in a more complex world. Today, young people need to negotiate contradictory messages about their "appropriate" roles at a time when "the traditional structural routes to adulthood no longer exist;" or when "the resources required for (the accepted transition to) adulthood have become impossible to obtain" (Philo and Swanson 2008, 198).

Third, the possibility of social agency and change is closely tied to the challenge of adopting "adult behavior at a younger age" (Ibid.). The course is designed to demonstrate how the everyday is political because we engage in both acceptance and resistance of our respective milieus as we go about our daily business. This is relevant to the course as young people make "claims for the importance of their everyday experience of social and political issues, and the personal, mundane and social arenas where they debate and take action on these issues" (Harris and Wyn 2009, 342).

Looking at the everyday works particularly well with juxtaposition. For example, rap music and soccer may be means to strengthen friendships, indulge in fun, or an attempt to capture normalcy in a time of war. New technologies, such as cell phones or the Internet, are transformed from mere conveniences into means of self-expression and political mobilization in highly conformist social settings. And the evolution of young people's multiple identities and self-understandings (e.g., being "deaf and lesbian" and "Scottish and Muslim") are complicated by processes of "glocalization," the threat of terrorism, and the upsetting of traditional roles.

\section{REFLECTING, COMPARING, AND CONVERSING: PEDAGOGY}

I use an interactive approach to learning as "research shows that the strongest gains come from pedagogies that feature teamwork and problem solving" (Carnes 2011). "Active learning," however, is more than just responding to questions; rather it is about developing a clearly sequenced teaching strategy that weaves together "information and ideas, experiences, and reflection" (Fink 2003, 106).

The new course discusses core concepts of $\mathrm{CP}$ covered in regular textbooks. However, we also discuss youth homelessness, education, drugs, social class, sexuality, urban-rural divides, the traditional roles of boys and girls, discipline, youth violence, selfexpression, globalization, civil war, apartheid, terrorism, postconflict situations, and local-level activism (see table 2). Class activities are based on materials that are conventional such as readings, lectures and discussions and nonconventional including investigative journalistic pieces, movies, popular culture, documentaries, YouTube, memoirs, websites, databases, and more. ${ }^{3}$

To make the concepts more tangible, the second component is crucial. "Experience," according to L. Dee Fink, is comprised of "doing" and "observing." Stories, case studies, documentaries and memoirs demonstrate the concepts and juxtapositions in action. This is also a way to look at youth action in the space between macro and micropolitics unfolding in different contexts. Thus, we discuss how a young man from the untouchable caste is trying to create a political party, how young people take advantage of glob- alization either through employment, the Internet, travel, or music, among others (see table 2).

Apart from "observing" other young people's lives, one significant class activity is group reportage on themes that recur throughout the course: (a) education and entitlement or "If I show up everyday to class, I deserve a B"; (b) hip-hop and rap or "That's not music"; (c) technology and multitasking; (d) YouTube, video games, and current events; (e) voting is for old people; and (f) immigrant lives or "growing up in America." Called "Educate the Professor," this activity is designed to gauge students' baseline knowledge of politics and community as well as to use their own experiences as examples throughout the course. It is also a way to create a positive atmosphere for sharing opinions and expressing dissent.

The final component in this teaching sequence is reflection, defined as helping "students to become more adept at meaning making, and that means they need to spend time reflecting on the meaning of the experiences and new ideas they acquire" (Fink 2003, 106). Apart from regular tests, the students write seven weekly "journal entries" and a final critical reflection essay.

Guide questions for the weekly journals are constructed to assess their understanding of the concepts and issues and their critical thinking skills. Students are asked to describe how they can improve in school, to identify the lessons learned, and to compare the young peoples' experiences with their own. For example, students explained Wattenberg's arguments and how his findings challenged them; they compared the different democracies of the United States, UK, India, and Japan, as well as the economic and social transitions in the China and the United States; they examined the educational systems in the United States and Japan; they studied the challenges of rebuilding a nation after a war; and they shared the obstacles they have overcome and how they have sustained themselves emotionally and spiritually. For the final critical reflection essay, the students integrated these journal entries with political concepts and issues. They discussed how politics affected their lives and the lives of the young people we studied, and what they learned from other young people. The goal of this assignment is to synthesize cases with concepts, highlight the relationship of self and others, and to connect the everyday micropolitics to macropolitics.

\section{ASSESSING THE JOURNEY}

This new course design was applied to another introductory CP course with a similar profile of students, that is, freshmen nonmajors, in spring 2009. The results were encouraging: a textual analysis of a random sample of 30 (out of 60) final papers showed that in 21 out of 30 papers students were able to correctly identify and use concepts; 22 out of 30 showed more than a fair understanding of countries; and 29 out of 30 correctly discussed the issues involved. The weekly journals also kept the students reading, and the students showed gradual improvement in thinking critically and comparatively. Apart from these results, other important achievements absent from the first iteration of this introductory course emerged.

First, the stories and juxtaposition of concepts and issues piqued the students' curiosity. They asked questions such as: why did this happen; what can be done about it; what are the lessons that we draw from this experience? Because they were curious about the origins of current situations, students were more open to learning about the "big stuff" that have long-interested comparativists-government structure, political economy, the 
development of the state-or are now being studied by a new cohort of scholars-ethnic conflict, war, religion.

Second, students were more engaged. This higher level of engagement was due, in part, to the unconventional material; the young protagonists in the stories, profiles, or memoirs; and because students were responsible for assessing their own performance for the week. In an anonymous evaluation designed and administered by the university at the end of term, many students wrote that they appreciated the focus on youth experiences in different settings, the course materials used, and the interactive nature of the course.

Perhaps the most important exercise that helped students feel heard and valued was the Educate the Professor exercise. The students were very creative in their presentations, and they provided background research on voting and education. Surprisingly, their views were more self-critical rather than defensive. And because the themes were recurring throughout the course, I was able to connect their own experiences as both subjects of politics and agents in their everyday politics to our lessons.

Finally, what about an appreciation of politics and their individual engagement? A textual analysis of the same sample of final ing more countries and political situations in the course. Another study is needed to assess further iterations of this course, as well as the long-term impact of this course design and pedagogy.

An "everyday politics" approach is not the sole method to teach an introductory course on comparative politics. The development of this course was difficult but, in the end, I was pleased that student reactions were positive. I learned much from them and was touched by how open they were in their journal entries and in our class discussions. As noted by Jean Bethke Elshtain, for young people the quotidian is not trivial; and as teachers, it is not for us to trivialize this:

Tending to the quotidian, to the politics of everyday life, helps us to keep our feet on the ground, our head out of the clouds. We understand that we need the saving presence of our fellow human beings. We appreciate fellowship and friendship as well as antagonism. We understand that theory is not a realm apart from life but, rather, a part of life, one of the activities that some of us are called to (1997, viii).

Finally, this was more than an introductory course on comparative politics; it became a journey into self-discovery, political aware-

\section{Perhaps the most important exercise that helped students feel heard and valued was the Educate the Professor exercise.}

papers was positive. Of the students who discussed their ideas about politics before taking the course, most said they were ignorant or disdainful of politics and were not very knowledgeable about their own government or other countries' political life. After the course, many students said that they have begun to recognize the impact of government on their everyday lives, as well as the need to pay attention to politics. The students also mentioned that they gained some knowledge about other countries' political systems.

There was also some evidence of empathy as students mentioned becoming aware of other young people's struggles and the potential for young people to make a difference. Thus, many of the students' papers showed that they were thinking about their individual engagement whether in the form of voting, becoming more knowledgeable about politics, or even possibly connecting with other youths in their community or beyond. Looking at how other young people struggle and overcome in more disadvantageous settings is empowering for many American students. Moreover, the writing exercises challenged the students' self-understandings by "nudging" them to think about complex political and social issues.

In the end, this exploratory approach to introductory $\mathrm{CP}$ courses focusing on the everyday and using an active learning strategy shows gains in student engagement and knowledge. The students also show an increased appreciation for the subject; develop a modicum of empathy, responsibility, and self-criticism; and realize the possibility of their individual political agency. Nevertheless, like all courses, there is still room for improvement. Some problems persist such as getting students to read and participate consistently. I also need to address developing a healthy appreciation of what students have without falling into the trap of American exceptionalism, preventing stereotyping, and includ- ness, social criticism, and individual engagement for both professor and students.

\section{ACKNOWLEDGMENTS}

An earlier version of this article was presented at the annual meeting of the Midwest Political Science Association, April 22, 2010, Chicago, Illinois. I would like to thank the conference participants, professor Eileen Barrett, and an anonymous reviewer for their comments which helped sharpen the focus of the article.

\section{NOTES}

1. Wilsford (1995) made a similar observation that the challenges included the students' passive educational experience, their parochialism, and lack of commitment to political science (221).

2. These textbooks are Danziger 2009; Drogus and Orvis 2009; Hauss 2009; O'Neil 2007; O'Neil, Fields, and Share 2007; Siaroff 2009; and Sodaro 2008.

3. The main textbooks were Jeffrey and Dyson 2008, and Wattenberg 2007. Supplemental readings and materials can be found in table 2.

\section{REFEREN C ES}

Anderson, Stephanie B. 2007. Government Formation in Parliamentary Democracies: A Simulation. Washington DC: Georgetown University Institute for the Study of Diplomacy.

Baumgartner, Jody C., and Jonathan S. Morris. 2010. "Myfacetube Politics: Social Networking Web Sites and Political Engagement of Young Adults." Social Science Computer Review 28 (1): 24-44.

Bennett, Stephen Earl, and Linda L.M. Bennett. 2001. "What Political Scientists Should Know about the Survey of First-Year Students in 2000." PS: Political Science and Politics 34 (2): 295-99.

Bucholz, Mary. 2002. "Youth and Cultural Practice." Annual Review of Anthropology 31: 525-52.

Burwell, Catherine. 2010. "Rewriting the Script: Toward a Politics of Young People's Digital Media Participation." Review of Education, Pedagogy and Cultural Studies 32 (4/5): 382-402. 
Carnes, Mark C. 2011. "Setting Students' Minds on Fire-Commentary." The Chronicle of Higher Education, March 6. http://chronicle.com/article/SettingStudents-Minds-on/126592/.

Chronicle of Higher Education (CHED). 2010. "This Year's Freshmen at 4-Year Colleges: Highlights of a Survey." The Chronicle of Higher Education, January 21. http://chronicle.com/article/This-Years-Freshmen-at-4-Year/63672/.

CIRCLE. 2010. Circle Fact Sheet 2010. The Center for Information and Research on Civic Learning and Engagement, November 9. http://www.civicyouth.org/wpcontent/uploads/2010/11/2010-Exit-Poll-Fact-Sheet.-corrected-Nov-10.pdf.

Clydesdale, Tim. 2007. The First Year Out: Understanding American Teens after High School. Chicago and London: University of Chicago Press.

Danziger, James N. 2009. Understanding the Political World: A Comparative Introduction to Political Science. 9th ed. New York: Pearson Longman.

Digeorgio Lutz, Jo Ann. 2010. "Becoming Global Citizens without Leaving Home." Teaching in Higher Education 15 (6): 715-20.

Drogus, Carol Ann, and Stephen Orvis. 2009. Introducing Comparative Politics: Concepts and Cases in Context. Washington DC: CQ Press.

Elshtain, Jean Bethke. 1997. Real Politics: At the Center of Everyday Life. Baltimore and London: The Johns Hopkins University Press.

Fink, L. Dee. 2003. Creating Significant Learning Experiences: An Integrated Approach to Designing College Courses. San Francisco: Jossey-Bass.

Fisher, Patrick. 2008. "Is There an Emerging Age Gap in US Politics?" Society 45 (6): 504-11.

Gaiser, Wolfgang, Martina Gille, Johanne De Rijke, and Sabine Sardei-Biermann. 2007. "Changes in the Political Culture of Young East and West Germans between 1992 and 2003." Journal of Contemporary European Studies 15 (3): 287-302.

Harris, Anita, and Johanna Wyn. 2009. "Young People's Politics and the MicroTerritories of the Local." Australian Journal of Political Science 44 (2): 327-44.

Hauss, Charles. 2009. Comparative Politics: Domestic Responses to Global Challenges. 6th ed. Belmont, CA: Wadsworth Cengage Learning.

Holt, Louise, and Sarah L. Holloway. 20o6. "Editorial: Theorising Other Childhoods in a Globalised World." Children's Geographies 4 (2): 135-42.

Jeffrey, Craig. 2008. “'Generation Nowhere': Rethinking Youth through the Lens of Unemployed Young Men.” Progress in Human Geography 32 (6): 739-58.

- and Jane Dyson, eds. 2008. Telling Young Lives: Portraits of Global Youth. Philadelphia: Temple University Press.

Juris, Jeffrey Scott, and Geoffrey Henri Pleyers. 2009. "Alter-Activism: Emerging Cultures of Participation among Young Global Justice Activists.” Journal of Youth Studies 12 (1): 57-75.

Keating, Avril, Tom Benton, and David Kerr. 2011. "Tracing the Trends and Transitions in Young People's Citizenship Practices: What Are the Implications for Researching Citizenship and Citizenship Education?" Educational Research 53 (2): $223-35$.

Kennelly, Jacqueline, Stuart Poyntz, and Paul Ugor. 2009. "Special Issue Introduction: Youth, Cultural Politics, and New Social Spaces in an Era of Globalization." Review of Education, Pedagogy \& Cultural Studies 31 (4): 255-69.

Lang, James M. 2008. “The Myth of First-Year Enlightenment.” In The Chronicle of Higher Education, February 1. http://chronicle.com/weekly/v54/i21/ 21c00101.htm.

Liu, Amy, Jessica Sharkness, and John H. Pryor. 2008. "Findings from the 2007 Administration of 'Your First College Year (YFCY)': National Aggregates." Los Angeles: Higher Education Research Institute, University of California.
Lopez, Mark Hugo, Peter Levine, Deborah Both, Abby Kiesa, Emily Hoban Kirby, and Karlo Barrios Marcelo. 2006. "The 2006 Civic and Political Health of the Nation: A Detailed Look at How Youth Participate in Politics and Communities." CIRCLE. http://www.civicyouth.org/PopUps/20o6_CPHS_Report_ update.pdf.

Lopez, Mark Hugo, and Karlo Barrios Marcelo. 2006. "Youth Demographics." CIRCLE.

McGlinchey, Eric M. 2009. "Searching for Kamalot: Political Patronage and Youth Politics in Uzbekistan." Europe-Asia Studies 61 (7): 1137-50.

O'Neil, Patrick. 2007. Essentials of Comparative Politics. 2nd ed. New York and London: W.W. Norton.

O'Neil, Patrick, Karl Fields, and Don Share. 2007. Cases in Comparative Politics. 2nd ed. New York and London: W.W. Norton.

Pacheco, Juliana. 2008. "Political Socialization in Context: The Effect of Political Competition on Youth Voter Turnout." Political Behavior 30 (4): 415-36.

Philo, Chris, and Fiona M. Smith. 2003. "Guest Editorial: Political Geographies of Children and Young People." Space and Polity 7 (2): 99-115.

Philo, Chris, and Kate Swanson. 2008. "Afterword: Global Portraits and Local Snapshots.” In Telling Young Lives:Portraits of Global Youth, eds. C. Jeffrey and J Dyson, 193-207. Philadelphia: Temple University Press.

Riley, Sarah C. E., Christine Griffin, and Yvette Morey. 2010. "The Case for 'Everyday Politics': Evaluating Neo-Tribal Theory as a Way to Understand Alternative Forms of Political Participation, Using Electronic Dance Music Culture as an Example." Sociology 44 (2): 345-63.

Russell, Andrew. 2004. "The Truth about Youth? Media Portrayals of Young People and Politics in Britain." Journal of Public Affairs 4 (4): 347-54.

Scott, James C. 1985. Weapons of the Weak: Everyday Forms of Peasant Resistance. New Haven and London: Yale University Press.

Shepler, Susan. 2010. "Youth Music and Politics in Post-War Sierra Leone." Journal of Modern African Studies 48 (14): 627-42.

Siaroff, Alan. 2009. Comparing Political Regimes: A Thematic Introduction to Comparative Politics. 2nd ed. Toronto: Higher Education University of Toronto Press.

Sodaro, Michael J. 20o8. Comparative Politics: A Global Introduction. New York: McGraw-Hill Higher Education.

Tam, Hau-lin. 2011. "'Delinquent Behaviour as a Kind of Body Politics' against Adult Regulations-Young People's Discourses in Hong Kong.” Children and Youth Services Review 33 (6): 878-87.

Topalova, Viktoriya. 2006. "In Search of Heroes: Cultural Politics and Political Mobilization of Youths in Contemporary Russia and Ukraine." Demokratizatsiya 14 (1): 23-41.

United Nations. 1996. "World Programme of Action for Youth to the Year 2000 and Beyond." Resolution of the General Assembly, A/RES/5o/81, March 13. http://www.un.org/esa/socdev/unyin/documents/wpay.pdf.

United Nations Department of Economic and Social Affairs. 20o6. World Population Prospects. New York: United Nations. http://www.un.org/esa/population/ publications/wpp2006/wpp20o6.htm.

von Hellermann, Pauline. 2010. "The Chief, the Youth, and the Plantation: Com munal Politics in Southern Nigeria." Journal of Modern African Studies 48 (2): 259-83.

Wattenberg, Martin P. 2007. Is Voting for Young People? With a Postscript on Citizen Engagement. 2nd ed. New York: Longman.

Wilsford, David. 1995. "Getting Students to Think (Comparatively): Teaching the Introductory Course in the 1990s." PS: Political Science and Politics 28 (2): 221-26. 